\title{
Rules of Taxation of Controlled Foreign Companies: A Comparative Study
}

\author{
Milyausha R. Pinskaya ${ }^{1}$, Nina I. Malis ${ }^{2} \&$ Nicolai S. Milogolov ${ }^{1}$ \\ ${ }^{1}$ Federal State Budgetary Institution "Scientific and Research Financial Institute", Moscow, Russia \\ ${ }^{2}$ Federal State-Funded Educational Institution of Higher Professional Education "Financial University under the \\ Government of the Russian Federation", Moscow, Russia \\ Correspondence: Milyausha R. Pinskaya, Federal State Budgetary Institution "Scientific and Research Financial \\ Institute”, Nastas’insky per, 3/2, 127006 Moscow, Russia. E-mail: mpinskaya@yandex.ru
}

Received: August 26, 2014 Accepted: October 24, 2014 Online Published: December 30, 2014

doi:10.5539/ass.v11n3p274 URL: http://dx.doi.org/10.5539/ass.v11n3p274

\begin{abstract}
This article is aimed at generalization of foreign practices of taxation of Controlled Foreign Companies in order to solve a problem of capital outflow to low-tax jurisdictions and at further elaboration of recommendations on reforming a concept of tax residence in the Russian Federation. The article summarizes elements of national taxation rules set in such countries as France, Great Britain, Germany, USA, China and Brazil. The article detects shortcomings of the Russian rules concerning Controlled Foreign Companies and suggests ways of their remedy. It makes a conclusion that taking into consideration the Russian environment the rules concerning CFC being elaborated require careful revision with regard to recommendations of Organization of Economic Cooperation and Development which will be made in 2015 within the framework of a "Base Erosion and Profit Shifting" program.
\end{abstract}

Keywords: profit, double taxation, tax residence, Controlled Foreign Company, offshore, low-tax jurisdiction

\section{Introduction}

Globalization of economy stimulates development of world trade, however, in most of developed countries in the world lack of proper control and limitation of incoming and outgoing flow of investments has caused the problem of taxable base erosion, referred to as "Base Erosion and Profit Shifting" (BEPS). In order to minimize their tax burden, national companies establish associated foreign companies which don't fall within the scope of the national tax legislation and distribute their assets, activities and risks between companies located in different countries. In order that resident companies should pay a tax on profit of foreign companies in the country of their residence, countries have elaborated the rules concerning Controlled Foreign Companies (CFC).

Issues of taxation of residents' arrivals from foreign sources and shift of a taxable base in low-income jurisdiction are extensively clarified both in scientific literature (Artem'ev \& Polezharova, 2013; Musaeva, 2013; Musaeva, 2014; Pogorletsky \& Sutyrin, 2010; Subpart, 2010; Morgan-Thomas, 2013; Andersson, 2006) and in the field of interstate cooperation (Declaration of the Summit on Financial Markets \& the World Economy, 2008, November 15; G'20 Leaders'Declaration, 2013, September, 6,). G20 has delivered relevant suggestions and instructions to Organization of Economic Cooperation and Development (OECD).

In order to solve the problem of BEPS in Russia, an idea of deoffshorization of the Russian economy has been suggested. It means working out government measures aimed at raising barriers for companies applying schemes of tax evasion by means of offshore centers. In 2014 the Ministry of Finance of the Russian Federation started elaboration of the rules concerning CFC (The Law of the Russian Federation "About making alterations in the first and the second parts of the Tax Code of the Russian Federation (as regards taxation of profit of controlled foreign companies and of income of foreign entities)", 2014), thus giving rise to public debates in scientific and business community.

\section{Methods}

Legislation concerning CFC considerably differs in different countries, at this it is relies on the same principles. A well-known theoretician of international taxation, Lars Eric Venehead, has elaborated a general rule concerning CFC, comprising the main features of certain rules existing in different countries: "If a company 
from one country is controlled by residents of another country who at the same time are members of this company, these persons will pay a tax on the full profit of the company if this profit has been handed to them with the purpose of tax evasion" (cited by: Andersson, 2006).

This rule comprises three key conditions which should be observed in order the rule concerning CFS will have effect. There should be: (1) a foreign company (2) controlled by a resident and (3) profit handed to the foreign company in order to evade taxes. In case the three conditions are observed the resident pays the tax on profit of the foreign company in the country of his residence.

Theoretically possible variants of different elements of the rules concerning CFC are described in Table 1.

Table 1. Variants of the rules concerning CFC

\begin{tabular}{|c|c|c|}
\hline \multicolumn{2}{|c|}{ An element of the rule concerning CFC } & Possible variants \\
\hline \multicolumn{2}{|c|}{ A foreign company } & $\begin{array}{l}\text { An organization with a separate and independent status for } \\
\text { taxation; } \\
\text { Unincorporated ventures (societies, trusts, partnerships, } \\
\text { associations and etc.) }\end{array}$ \\
\hline \multirow{2}{*}{ Control } & Control implementation & $\begin{array}{l}\text { Ownership of certain capital share, voting shares or } \\
\text { dividend entitlement }\end{array}$ \\
\hline & A controller & $\begin{array}{l}\text { A natural person, partnership, organization, association or a } \\
\text { public body, a group of mutually dependent persons }\end{array}$ \\
\hline \multirow{2}{*}{\multicolumn{2}{|c|}{ Profit transferred in order to evade taxes }} & $\begin{array}{l}\text { A method of transactions analysis - only passive income is } \\
\text { subject to tax }\end{array}$ \\
\hline & & $\begin{array}{l}\text { A method of jurisdictions - profit transferred to countries } \\
\text { from a "black list" }\end{array}$ \\
\hline \multirow{5}{*}{$\begin{array}{l}\text { Detection of a } \\
\text { taxable base of a } \\
\text { CFC }\end{array}$} & A moment of base incurrence & A moment of transference of CFC profit \\
\hline & Procedure of the CFC base & Rules of a country of taxpayer's residence \\
\hline & detection & Rules of a country of CFC's registration \\
\hline & CFC profit qualification & Nominal dividends \\
\hline & $\mathrm{CFC}$ protit qualitication & Profit from operations \\
\hline
\end{tabular}

Let us carry out a comparative study of rules concerning CFC existing in developed countries and the rules being elaborated in Russia. For the purposes of this article we outline the following elements of the national rules of taxation established in different countries:

1) A system of taxation of resident companies profit (geographically-based or universal);

2) what companies can be classified as CFC;

3) a mechanism of detection of the presence of control;

4) a way of detection of profit transferred in order to evade taxes;

5) a mechanism of elimination of double taxation (profit analysis; jurisdiction analysis);

6) exemption from the rules concerning CFC;

7) profit qualification and possibility to integrate a taxable base of a CFC with that of its member;

8) administration of the rules concerning CFC.

Let us consider special aspects of the rules considering CFC, set in such countries as France (Gutmann \& Meziane, 2014; France International tax highlights, 2014), Great Britain (United Kingdom International tax highlights, 2014), Germany (Germany International tax highlights, 2014; The Guide to Controlled Foreign Company Regimes (updated as of January 2014), 2014), USA (The Guide to Controlled Foreign Company Regimes (updated as of January 2014), 2014; USA International tax highlights, 2014), China (The Guide to Controlled Foreign Company Regimes (updated as of January 2014), 2014; China International tax highlights, 2014) and Brazil (The Guide to Controlled Foreign Company Regimes (updated as of January 2014), 2014; Brazil International tax highlights, 2014), and the rules being elaborated in Russia (The Law of the Russian Federation "About making alterations in the first and the second parts of the Tax Code of the Russian Federation (as regards taxation of profit of controlled foreign companies and of income of foreign entities)", 2014), taking into account the above stated elements.

More detailed rules concerning CFC existing in France, Great Britain, Germany, USA, China and Brazil and those being elaborated in Russia are described in Appendix 1. 


\section{Results}

3.1 Comparison of Entities Falling within the Scope of the Rules Concerning CFC, the Mechanism of Detection of Control and the Method of Profit Detection

1) In the world there are two systems of profit taxation of resident companies: universal and geographically-based.

In Germany, USA, China, Brazil and Russia the universal system is in effect. In particular, in Russia the organization profit tax is imposed on: income of Russian organizations from sources all over the world; income of foreign organizations from activity in Russia through permanent representative offices; passive income of foreign organizations from sources in the Russian Federation. Countries with the universal system of taxation are entitled to impose taxes on income of their residents and their permanent representative offices all over the world and the rules concerning CFC are one of their tools to detect such income and impose a tax on it.

France and Great Britain have to make an exception in their geographically-based system and impose a tax on income of CFC according to the universal taxation system. For instance, in France permanent missions are subject to taxes.

2) The rules concerning CFC basically covers foreign subsidiaries, but in many cases have effect also for different unincorporated entities which are established according to foreign legislation and can be used for tax evasion, as well as permanent representative offices.

In all the countries subsidiaries from studied countries can be possibly considered to be controlled. The rules concerning CFC apply to permanent representative offices in France and Great Britain. In France, apart from subsidiaries, profit and non-profit organizations, trusts, association, partnerships, consortiums, fiduciary agreements and etc. can be considered to be controlled. In Brazil these rules apply to affiliated companies. Though the rules concerning CFC in Germany do not apply to various unincorporated entities, these entities, if established for tax evasion, are subject for additional rules preventing abuse.

3) In studied countries mechanisms of control detection for the purposes of the rules concerning CFC, are different. Controllers can be represented both by natural persons and companies and in France and Great Britain - only by companies. At this in any case one of the variants of detecting the fact of control over a foreign company is detection of a share in the foreign company. A limit of participation is from $50 \%$ (France, Germany and USA) to $10 \%$ (China). The limit of $10 \%$ is established in China for the cases when only one associated person is a member of a controlled foreign company, while in case of communal ownership a limit of $50 \%$ exists. In France and in Germany the limit may be pulled down to 5\% and 1\% respectively subject to certain conditions (if a company is engaged in certain financial transactions). In Brazil the fact that "an investor has significant influence and a right to make decisions concerning a company" (Brazil International tax highlights, 2014) is also a crucial factor to acknowledge the presence of control.

4) Since the rules concerning CFC are aimed at struggle against tax evasion by means of profit transfer to a foreign company, the most important part of the rules concerning CFC is a method of detection of profit transferred for tax evasion. For this purpose methods of transaction analysis and of jurisdiction can be used, and many countries apply both of them simultaneously.

In France, China and Brazil the whole profit without division into passive and active is taxable according to the rules concerning CFC. In Germany, Great Britain and USA taxes are imposed only on a part of CFC profit.

In case of the method of jurisdiction a "black list" is not used for detection of profit transferred for tax evasion in any of the considered countries and a "white list" exists only in China. Instead legislation concerning CFC stipulates a minimum effective interest rate for a profit tax. If in a CFC's country this rate is lower, the company is subject to taxation. Thus in France the rule is applied to all countries where the efficient interest rate for the tax profit is equal to $50 \%$ or lower than in France. In Germany the rule is applied to all countries where the efficient interest rate for the tax profit is less than $25 \%$. In China the rule is applied to all countries where the efficient interest rate for the tax profit is less than $25 \%$.

\subsection{Comparison of the Mechanisms of Double Taxation Elimination, Exemption and Administration}

5) In these countries there are mechanisms of elimination of double taxation of CFC's profit. First of all, they include a possibility of deducting a tax paid in the country of a CFC from the base, and, secondly, no repeated taxation of CFC's dividends in case they are distributed after taxation in the framework of the rules concerning CFC. In all the countries considered the tax paid in the country of a CFC is deducted. 
In order to prevent repeated taxation of dividends it is necessary to have full or partial participation exemption of dividends gained from foreign subsidiaries. This rule exists in France, Germany and Great Britain, but is lacking in the other chosen countries. In USA dividends gained by a mother company from a CFC are free from taxes after its profit taxation within the scope o the rules concerning CFC, since they are classified as "formerly taxed profit". In China dividends gained by a mother company from a CFC are free from taxes after its profit taxation within the scope o the rules concerning CFC. In Brazil participation exemption is in effect only with regard to dividends gained from Brazil companies, while dividends gained by the mother company from a $\mathrm{CFC}$ are exempted from taxes after its profit taxation within the scope o the rules concerning CFC.

6) Exemption from the rules concerning CFC is a key element of the rules concerning CFC since it helps to separate companies using their foreign branches for business purposes from those using them with tax motives. In Germany and France the rules concerning CFC are not applied to companies from EC members (excluding using artificial structures). This is aimed at compliance with the supernational legislation existing in all EC members.

In Great Britain companies with income by $10 \%$ or less exceeding costs of organizations from a number of countries (mainly those where a tax rate is higher than $75 \%$ of the British) or organizations which have already paid a tax equal to $75 \%$ or higher than the British one are exempt from their taxpaying duties within the scope of the rules concerning CFC. Besides, there is a special system of exemption for financial companies.

In France profit of a CFC is exempt from taxation if it has been gained from some activity (but no more than $20 \%$ of profit has been gained from activity related to holding management, granting a loan on one's own behalf or on behalf of associated organization as well as to granting licenses, rights and intangible assets). At this the burden of proof that the profit has been gained from some activity is practically imposed on a taxpayer.

In a number of countries a minimum limit of income of a CFC is stipulated. In case it is surpassed the company falls into the scope of the rules. These measures are taken for reasons of tax administration.

7) For taxation purposes qualification of CFC's profit as nominal dividends or as profit from operation influences: the amount of a tax rate (it is generally lower for dividends), the conflict between the rules concerning CFC and a Treaty on prevention of double taxation, as well as a possibility of integrating the taxable base of a CFC with the internal tax base. Different countries apply different approaches.

In France and Germany for the taxation purposes profit of subsidiaries is considered to be "nominal dividends" and can't be integrated with the taxable base of a taxpayer. In France profit of permanent representative offices is acknowledged as profit from operations and can be integrated with the base of a taxpayer, while in Brazil such profit can optionally be integrated or not integrated with the base of a taxpayer.

8) Administration of the rules concerning CFC is one of the most complex element of exercising the rules concerning CFC, since for their efficiency well-functioning mechanisms of information exchange between tax authorities from different countries are required. In all the considered countries there exists a duty to notify of participation in a CFC, and for the taxation purposes profit of a CFC is calculated according to local rules. In Great Britain there is a duty of regular reporting profit transferred to a foreign company in statements and carrying out tests defining whether the foreign company is a CFC. In USA there are strict requirements for keeping and delivering reports concerning CFC and heavy fines for their violation. In China a taxpayer fills in an annual statement of foreign investments and a tax authority defines the fact of CFC existence.

\section{Discussion}

The best foreign practices are subject to close examination in the course of elaboration of the Russian rules concerning CFC. The main point of the rules concerning CFC is that in the Russian Federation a tax resident of Russia (both a legal entity and a natural person) should pay a tax on retained profit of controllable offshore organizations and entities which do not pay dividends.

Most of typically used business structures would be affected by the proposed CFC legislation (see figure 1).

As we can see from figure 1 typical structures used by Russian business include a high tax jurisdictions (usually Cyprus, Luxembourg and Netherland) which have tax treaties with correspondent offshores. All these intermediate jurisdictions can be caught by proposed CFC rules because they would not pass "effective rate" test.

At this it is offered to establish "loose" rules concerning CFC which will stipulate taxation of organization profit in "another" state in case this organization complies with requirements of CFC. The French practice has shown that similar conflict between the "loose" rules concerning CFC and the Treaty on prevention of double taxation concluded according to the pattern of an OECD model convention caused well-known legal proceedings 
between France and Switzerland (Schneider Electric). After this the CFC profit started to be qualified as "nominal dividends" and the rules were applied mainly on artificial structures (Lauritzen \& Lif, 2005).

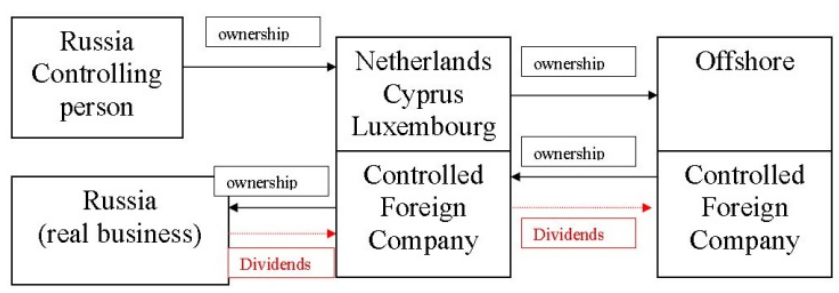

Figure 1. Typical offshore structures of Russian business

It is considered to be reasonable to use a "black list" of jurisdictions with which the Russian Federation has no such treaties for the purposes of the rules concerning CFC and to introduce more tight rules CFC. As far as it regards countries with which the Russian Federation has concluded Treaties on prevention of double taxation, it is reasonable to use these treaties as a tool for struggle against tax abuse. Such possibility is stipulated by these treaties. A separate article of BEPS program (Public Discussion Draft BEPS Action 6: Preventing the Granting of Treaty Benefits in Inappropriate Circumstances. OECD, 2014) is dedicated to study of this possibility. Instead of the "loose" rules concerning CFC the rules aimed at struggle against artificial structures set for tax evasion, should be applied.

It is supposed that profit of CFC should be qualified as "nominal dividends", since it accords with its economic substance, and consequently apply the rate used for dividends. Besides qualification of CFC profit as "nominal dividends" will prevent a potential conflict between the rules concerning CFC and article 7 of the Treaties on prevention of double taxation concluded by the Russian Federation and applied to profit from business activity but not to dividends. It is necessary to include into a taxable base only passive CFC profit, since it accords with the above stated approach of transactions analysis (active profit has been gained from certain activity but not for abuse).

Among drawbacks there should be also noted a too low limit for notification and for payment of the tax on CFC profit (1 and 10\%) and a high level of additional administration load on business due to the need of translation of CFC's financial statements into Russian, mandatory auditing, a complex procedure of profit calculation (active and passive profit separately).

\section{Conclusion}

To prevent transferring profit gained as dividends, interest or royalties, of resident companies to a foreign company located in a country with a favourable tax regime, the countries elaborate the rules concerning CFC based on the similar principles.

Nowadays in the Russian Federation the rules concerning CFC are actively elaborated with due regard to the positive practice of developed foreign countries. For comparison of the Russian rules concerning CFC with the best world practices we have chosen countries applying different taxation systems: geographically-based (France and Great Britain) and universal (Germany, USA, China and Brazil).

The Russian rules being worked out do not fundamentally differ from the foreign ones, but are significantly worse elaborated. In particular, they stipulate taxation of profit of a company located in another state if the company can be qualified as a controlled foreign company. Such a procedure conflicts with the concluded treaties on prevention of double taxation.

The above stated recommendations can be used in case of making a decision to introduce a law concerning CFC for approval by the State Duma of Russian Federation in 2014. However, we consider adoption of the law concerning CFC to be untimely since introduction of this measure should be elaborated more thoroughly. In 2015 the problem of CFC will be considered within the framework of BEPS program and it seems reasonable to wait for OECD recommendations concerning this issue. Besides regarding economic sanctions imposed by EC members and USA on Russian companies, introduction of the rules concerning CFC can cause additional problems for these companies in the course of their activity on the world's markets.

The Russian rules concerning CFC are in the course of elaboration, they have not been yet adopted as a regulatory act that is why it is impossible to assess positive and negative consequences of their application. 


\section{References}

Andersson, S. (2006). CFC rules and double tax treaties. The OECD and UN model tax conventions. Jönköping International Business School Jönköping University. Retrieved March 18, 2014, from http://www.divaportal.org/smash/get/diva2:4297/FULLTEXT01.pdf.

Artem'ev, A., \& Polezharova, L. (2013). Taxation of members of international economic activity in Russia: A textbook (Ed.: L. Goncharenko). Moscow: Magistr. INFRA-M. ISBN 978-5-9776-0265-5.

Brazil International tax highlights. (2014). Retrieved May 14, 2014, from http://www2.deloitte.com/content/ dam/Deloitte/global/Documents/Tax/dttl-tax-brazilhighlights-2014.pdf

Declaration of the Summit on Financial Markets and the World Economy, Washington DC. (2008, November 15). Retrieved July 19, 2014, from http://www.g20.utoronto.ca/2008/2008declaration1115.html

France International tax highlights. (2014). Retrieved May 14, 2014, from http://www2.deloitte.com/content/ dam/Deloitte/global/Documents/Tax/dttl-tax-francehighlights-2014.pdf

G'20 Leaders' Declaration. St. Petersburg. (2013, September 6). Retrieved July 19, 2014, from http://www.g20.utoronto.ca/2013/2013-0906-declaration.html

Germany International tax highlights. (2014). Retrieved May 14, 2014, from http://www2.deloitte.com/content/ dam/Deloitte/global/Documents/Tax/dttl-tax-germanyhighlights-2014.pdf

Gutmann, D., \& Meziane F. (2014). The French CFC Regime. American tax policy institute. Retrieved May 14, 2014, from http://www.americantaxpolicyinstitute.org/pdf/Arnold\%20paper.pdf.

Lauritzen, J. S., \& Lif, B. K. (2005). CFC Legislation in an International Tax Perspective. Private, 4, 28-30. Retrieved May 20, 2014, from http://www.kendris.com/files/elemente/pdf/news_en112.pdf

Morgan-Thomas, M. (2013, November). Countering Offshore Tax Evasion: A Comparative Look at Initiatives by the United States, Canada, the United Kingdom and Japan. International Journal of Business and Social Science, 15(Special Issue 4), 17-27.

Musaeva, Kh. (2013). Institutional Aspects of Tax Planning in the Conditions of Reforming of Tax System and Improvement of Tax Management. World Applied Sciences Journal, 27(5), 643-648. http://dx.doi.org/10.5829/idosi.wasj.2013.27.05.13685.

Musaeva, Kh. (2014). The increase of tax administration effectiveness, as a factor of shadow sector validation and growth of economic security. Life Science Journal, 11(7s), 229-233. ISSN: 1097-8135 Retrieved July 18, 2014, from http://www.lifesciencesite.com/lsj/life1107s/046_24554life1107s14_229_233.pdf

Pogorletsky, A., \& Sutyrin, S. (2010). Prospects of establishment of a system of global tax regulation. Bulletin of Saint-Petersburg State University. "Economy" series, 2(5), 47-59. Retrieved July 18, 2014, from http://www.econ.spbu.ru/faculty/vestnik_st_petersburg_state_university_series_economies/archive/2010/iss ue_2/index.php

Public Discussion Draft BEPS Action 6: Preventing the Granting of Treaty Benefits in Inappropriate Circumstances. OECD. (2014). Retrieved July 18, 2014, from http://www.oecd.org/ctp/treaties/treatyabuse-discussion-draft-march-2014.pdf

Subpart, F. (2010). Rules on Taxation of Controlled Foreign Corporations. Navigating the Complexities in Tax Planning for Multinational Companies. Strafford. Retrieved July 12, 2014, from http://www.media. straffordpub.com/products/subpart-f-rules-on-taxation-of-controlled-foreign-corporations-2010-03-09/prese ntation.pdf

The Guide to Controlled Foreign Company Regimes. (2014, January). Retrieved May 14, 2014, from http://ww w2.deloitte.com/content/dam/Deloitte/global/Documents/Tax/dttl-tax-guide-to-cfc-regimes-210214.pdf.

The Proposed Law of the Russian Federation "About making alterations in the first and the second parts of the Tax Code of the Russian Federation (as regards taxation of profit of controlled foreign companies and of income of foreign entities)”. (2014). Retrieved July 26, 2014 from http://regulation.gov.ru/project/ 13067.html?point $=$ view_project\&stage $=3 \&$ stage_id $=9140$

United Kingdom International tax highlights. (2014). Retrieved May 14, 2014, from http://www2.deloitte.com/ content/dam/Deloitte/global/Documents/Tax/dttl-tax-unitedkingdomhighlights-2014.pdf.

USA International tax highlights. (2014). Retrieved May 14, 2014, from http://www2.deloitte.com/content/dam/ Deloitte/global/Documents/Tax/dttl-tax-unitedstateshighlights-2014.pdf 


\section{Appendix}

Appendix 1. The rules concerning CFC existing in France, Great Britain, Germany, USA, China and Brazil and those being elaborated in Russia

\begin{tabular}{|c|c|c|c|c|c|c|c|}
\hline A country & France & Great Britain & Germany & USA & China & Brazil & Russia \\
\hline $\begin{array}{c}\text { 1) A system of } \\
\text { profit taxation of } \\
\text { resident companies }\end{array}$ & Geographically-based & Geographically-based & Universal & Universal & Universal & Universal & Universal \\
\hline $\begin{array}{l}\text { 2) Companies } \\
\text { which can be } \\
\text { classified as CFC }\end{array}$ & $\begin{array}{c}\text { Subsidiaries, } \\
\text { permanent } \\
\text { representative offices, } \\
\text { profit \& non-profit } \\
\text { organizations, trusts, } \\
\text { associations, partner- } \\
\text { ships, consortiums, } \\
\text { fiduciary agreements } \\
\text { \& etc. }\end{array}$ & $\begin{array}{l}\text { Subsidiaries, permanent } \\
\text { representative offices } \\
\text { and foreign companies }\end{array}$ & $\begin{array}{l}\text { Subsidiaries } \\
\text { and foreign } \\
\text { companies }\end{array}$ & $\begin{array}{l}\text { Subsidiaries and } \\
\text { foreign companies }\end{array}$ & $\begin{array}{l}\text { Subsidiaries } \\
\text { and foreign } \\
\text { companies }\end{array}$ & $\begin{array}{l}\text { Subsidiaries, } \\
\text { associated } \\
\text { companies } \\
\text { and foreign } \\
\text { companies }\end{array}$ & $\begin{array}{l}\text { Subsidiaries, } \\
\text { foreign } \\
\text { companies, } \\
\text { foreign } \\
\text { organization and } \\
\text { unincorporated } \\
\text { entities }\end{array}$ \\
\hline $\begin{array}{l}\text { 3) A mechanism of } \\
\text { control detection } \\
\text { (limits of ownership } \\
\text { and a subject of } \\
\text { control } \\
\text { (organizations, } \\
\text { natural persons, } \\
\text { entities)) }\end{array}$ & $\begin{array}{c}\text { The limit of } \\
\text { ownership- } 50 \% \\
\text { (may be lowered to } \\
5 \% \text { ). } \\
\text { Controlled by a } \\
\text { French company; } \\
\text { associated persons - } \\
\text { residents of France. }\end{array}$ & $\begin{array}{c}\text { The limit of ownership- } \\
25 \% \text {. } \\
\text { Controlled by a } \\
\text { company; associated } \\
\text { persons - residents of } \\
\text { Great Britain. }\end{array}$ & $\begin{array}{l}\text { The limit of } \\
\text { ownership-- } \\
50 \% \text {, (may be } \\
\text { lowered to } 1 \% \text {, } \\
\text { if a company is } \\
\text { engaged in } \\
\text { certain } \\
\text { financial } \\
\text { transactions). } \\
\text { Controlled by a } \\
\text { company or a } \\
\text { natural person; } \\
\text { associated } \\
\text { persons - } \\
\text { residents of } \\
\text { Germany. }\end{array}$ & $\begin{array}{c}\text { The limit of } \\
\text { ownership- } 50 \% \text {. } \\
\text { Controlled by a } \\
\text { natural person or a } \\
\text { company; associated } \\
\text { persons; trusts, } \\
\text { societies and etc. - } \\
\text { residents of USA. }\end{array}$ & $\begin{array}{c}\text { The limit of } \\
\text { ownership- } \\
10 \% \text { (owned } \\
\text { by one } \\
\text { person) or } \\
50 \% \\
\text { (collectively). } \\
\text { Controlled by } \\
\text { a company or } \\
\text { a natural } \\
\text { person; } \\
\text { associated } \\
\text { persons - } \\
\text { residents of } \\
\text { China. }\end{array}$ & $\begin{array}{l}\text { The limit of } \\
\text { ownership - } \\
\text { an investor } \\
\text { has } \\
\text { significant } \\
\text { influence \& a } \\
\text { right to make } \\
\text { decisions } \\
\text { concerning } \\
\text { the company } \\
\text { or he owns a } \\
\text { share over } \\
20 \% \text {. } \\
\text { Controlled by } \\
\text { a company or } \\
\text { a natural } \\
\text { person; } \\
\text { associated } \\
\text { persons - } \\
\text { residents of } \\
\text { Brazil. }\end{array}$ & $\begin{array}{l}\text { The limit of } \\
\text { ownership- } \\
10 \% \text {. } \\
\text { Controlled by a } \\
\text { company or a } \\
\text { natural person; } \\
\text { associated } \\
\text { persons - } \\
\text { residents of } \\
\text { Russia. }\end{array}$ \\
\hline $\begin{array}{l}\text { 4) A method of } \\
\text { detection of profit } \\
\text { transferred for tax } \\
\text { evasion } \\
\text { (a transactions } \\
\text { analysis approach; a } \\
\text { jurisdiction } \\
\text { approach) }\end{array}$ & $\begin{array}{c}\text { Full profit is } \\
\text { accounted without } \\
\text { division into passive } \\
\text { and active. } \\
\text { The rule is applied to } \\
\text { all countries where an } \\
\text { efficient interest rate } \\
\text { for a profit tax is } \\
\text { equal to 50\% or lower } \\
\text { than in France. } \\
\text { No "black" and } \\
\text { "white" lists. }\end{array}$ & $\begin{array}{l}\text { The sum of taxable } \\
\text { profit is calculated by } \\
\text { an established } \\
\text { procedure including } \\
\text { analysis of: } \\
\text { 1) existence of non-tax } \\
\text { motives of a CFC; } \\
\text { 2) presence of assets } \\
\text { managed from Great } \\
\text { Britain; } \\
\text { 3) dependence of a CFC } \\
\text { from a company in } \\
\text { Great Britain; } \\
\text { 4) duties of important } \\
\text { persons in a company } \\
\text { with regard to CFC's } \\
\text { assets and risks. } \\
\text { The rules are applied to } \\
\text { all countries. } \\
\text { No "black" and "white" } \\
\text { lists. }\end{array}$ & $\begin{array}{l}\text { Only passive } \\
\text { profit is taken } \\
\text { into account. } \\
\text { The rule is } \\
\text { applied to all } \\
\text { countries } \\
\text { where an } \\
\text { efficient } \\
\text { interest rate for } \\
\text { a profit tax is } \\
\text { lower than } \\
25 \% \text {. } \\
\text { No "black" and } \\
\text { "white" lists. }\end{array}$ & $\begin{array}{l}\text { The tax is imposed } \\
\text { on the following } \\
\text { types of profit: } \\
\text { 1) underwriting } \\
\text { profit; } \\
\text { 2) profit of a foreign } \\
\text { core company } \\
\text { (including profit } \\
\text { from dividends, } \\
\text { interests, royalties, } \\
\text { rental income, some } \\
\text { types of income from } \\
\text { transactions with } \\
\text { associated persons; } \\
\text { some types of } \\
\text { income from oil } \\
\text { transactions; } \\
\text { 3) profit gained in } \\
\text { countries on which } \\
\text { sanctions are } \\
\text { imposed; } \\
\text { 4) illegal payments } \\
\text { to foreign agents or } \\
\text { governments. } \\
\text { No "black" and } \\
\text { "white" lists. }\end{array}$ & $\begin{array}{l}\text { Full profit } \\
\text { without } \\
\text { division into } \\
\text { passive and } \\
\text { active. } \\
\text { The rule is } \\
\text { applied to all } \\
\text { countries } \\
\text { where an } \\
\text { efficient } \\
\text { interest rate } \\
\text { for a profit } \\
\text { tax is equal to } \\
50 \% \text { or lower } \\
\text { than in } \\
\text { China. } \\
\text { There is a } \\
\text { "white" list. }\end{array}$ & $\begin{array}{l}\text { Full profit } \\
\text { without } \\
\text { division into } \\
\text { passive and } \\
\text { active. } \\
\text { No "black", } \\
\text { and "white" } \\
\text { lists. }\end{array}$ & $\begin{array}{l}\text { Only passive } \\
\text { profit. } \\
\text { The rules } \\
\text { concerning CFC } \\
\text { are applied to all } \\
\text { countries where } \\
\text { an efficient } \\
\text { interest rate for a } \\
\text { profit tax is } \\
\text { equal to } 75 \% \text { or } \\
\text { lower than in } \\
\text { Russia. } \\
\text { There is a } \\
\text { "white" list. }\end{array}$ \\
\hline $\begin{array}{l}\text { 5) A mechanism of } \\
\text { double taxation } \\
\text { elimination } \\
\text { (deduction of a tax } \\
\text { paid in the country } \\
\text { of a CFC and } \\
\text { exemption of } \\
\text { dividends } \\
\text { distributed from } \\
\text { profit). }\end{array}$ & $\begin{array}{c}\text { A sum of the tax paid } \\
\text { in the country of a } \\
\text { CFC is deducted from } \\
\text { taxable profit of the } \\
\text { CFC. } \\
\text { Participation } \\
\text { exemption (the limit } \\
\text { of participation is } \\
5 \% \text { ). }\end{array}$ & $\begin{array}{c}\text { A sum of the tax paid in } \\
\text { the country of a CFC is } \\
\text { deducted from taxable } \\
\text { profit of the CFC. } \\
\text { Participation exemption } \\
\text { (the limit of } \\
\text { participation is } 10 \% \text { ) }\end{array}$ & $\begin{array}{l}\text { A sum of the } \\
\text { tax paid in the } \\
\text { country of a } \\
\text { CFC is } \\
\text { deducted from } \\
\text { taxable profit } \\
\text { of the CFC. } \\
\text { If the CFC is } \\
\text { located in a } \\
\text { country which } \\
\text { doesn't provide } \\
\text { information } \\
\text { according to } \\
\text { the OECD } \\
\text { requirements, } \\
\text { the costs are } \\
\text { not deducted. } \\
\text { Participation } \\
\text { exemption (the } \\
\text { limit of } \\
\text { participation is } \\
5 \% \text { (the } \\
\text { minimum limit } \\
\text { of } \\
\text { participation). }\end{array}$ & $\begin{array}{l}\text { A sum of the tax } \\
\text { paid in the country of } \\
\text { a CFC is deducted } \\
\text { from taxable profit } \\
\text { of the CFC (only for } \\
\text { companies, but not } \\
\text { for natural persons). } \\
\text { In general cases } \\
\text { there is no } \\
\text { participation } \\
\text { exemption, but } \\
\text { dividends gained by } \\
\text { a mother company } \\
\text { from a CFC after its } \\
\text { profit has been taxed } \\
\text { within the scope of } \\
\text { the rules concerning } \\
\text { CFC, are exempt } \\
\text { from the tax since } \\
\text { they are qualified as } \\
\text { "formerly taxed } \\
\text { profit". }\end{array}$ & $\begin{array}{l}\text { A sum of the } \\
\text { tax paid in } \\
\text { the country } \\
\text { of a CFC is } \\
\text { deducted } \\
\text { from taxable } \\
\text { profit of the } \\
\text { CFC. } \\
\text { No } \\
\text { participation } \\
\text { exemption, } \\
\text { but dividends } \\
\text { gained by a } \\
\text { mother } \\
\text { company } \\
\text { from a CFC } \\
\text { after its profit } \\
\text { has been } \\
\text { taxed within } \\
\text { the scope of } \\
\text { the rules } \\
\text { concerning } \\
\text { CFC, are } \\
\text { exempt from } \\
\text { the tax. }\end{array}$ & $\begin{array}{l}\text { A sum of the } \\
\text { tax paid in the } \\
\text { country of a } \\
\text { CFC is } \\
\text { deducted } \\
\text { from taxable } \\
\text { profit of the } \\
\text { CFC. } \\
\text { Participation } \\
\text { exemption } \\
\text { only with } \\
\text { regard to } \\
\text { dividends } \\
\text { gained from } \\
\text { Brazilian } \\
\text { companies. } \\
\text { At this, } \\
\text { dividends } \\
\text { gained by a } \\
\text { mother } \\
\text { company } \\
\text { from a CFC } \\
\text { after its profit } \\
\text { has been } \\
\text { taxed within } \\
\text { the scope of } \\
\text { the rules } \\
\text { concerning } \\
\text { CFC, are } \\
\text { exempt from }\end{array}$ & $\begin{array}{l}\text { A sum of the tax } \\
\text { paid in the } \\
\text { country of a } \\
\text { CFC is deducted } \\
\text { from taxable } \\
\text { profit of the } \\
\text { CFC. } \\
\text { Participation } \\
\text { exemption (the } \\
\text { limit of } \\
\text { participation is } \\
50 \% \text { ). }\end{array}$ \\
\hline
\end{tabular}




\begin{tabular}{|c|c|c|c|c|c|c|c|}
\hline & & & & & & the tax. & \\
\hline $\begin{array}{l}\text { 6) Exemption from } \\
\text { the rules concerning } \\
\text { CFC }\end{array}$ & $\begin{array}{c}\text { EC companies } \\
\text { (excluding cases } \\
\text { when artificial } \\
\text { structures are used) } \\
\text { are exempt. } \\
\text { Profit of CFC gained } \\
\text { from certain activity } \\
\text { (but not exceeding } \\
20 \% \text { of profit gained } \\
\text { from holding } \\
\text { management, granting } \\
\text { a loan on its own } \\
\text { behalf or on behalf of } \\
\text { associated } \\
\text { organizations, as well } \\
\text { as granting licenses, } \\
\text { rights and intangible } \\
\text { assets) is exempt. } \\
\text { A company is } \\
\text { exempt, if it is located } \\
\text { outside EC and can } \\
\text { prove that it is } \\
\text { established with } \\
\text { purposes other than } \\
\text { tax evasion. }\end{array}$ & $\begin{array}{l}\text { Companies are exempt } \\
\text { with taxable profit } \\
\text { below } 50,000 \text { pounds or } \\
\text { with taxable profit } \\
\text { below } 50,000 \text { pounds } \\
\text { but the profit has been } \\
\text { gained through } \\
\text { non-trading activity and } \\
\text { is below } 50,000 \text { pounds. } \\
\text { Companies with income } \\
\text { exceeding costs by } 10 \% \\
\text { or less. Organizations } \\
\text { from a number of } \\
\text { countries (mainly those } \\
\text { where a tax rate is more } \\
\text { than } 75 \% \text { of the British } \\
\text { rate), as well as } \\
\text { organization which have } \\
\text { already paid the tax } \\
\text { equal to over than } 75 \% \\
\text { or more than the British } \\
\text { tax rate. A special } \\
\text { system of exemption for } \\
\text { financial companies. }\end{array}$ & $\begin{array}{l}\text { Companies } \\
\text { from EC, trusts } \\
\text { for real estate } \\
\text { investments, } \\
\text { certain types of } \\
\text { investments. }\end{array}$ & $\begin{array}{l}\text { Profit which have } \\
\text { already been taxed } \\
\text { according to a high } \\
\text { efficient rate and } \\
\text { profit of securities } \\
\text { dealers. } \\
\text { Certain types of } \\
\text { income gained from } \\
\text { CFC (not passive or } \\
\text { income according the } \\
\text { principle } \\
\text { "pass-through" } \\
\text { taxation in } \\
\text { compliance with } \\
\text { temporary provision } \\
\text { in force since } \\
\text { January, 1, 2014). }\end{array}$ & $\begin{array}{l}\text { Companies } \\
\text { from a } \\
\text { "white" list } \\
\text { and those } \\
\text { CFC whose } \\
\text { profit has } \\
\text { been gained } \\
\text { from certain } \\
\text { activity or } \\
\text { with annual } \\
\text { profit below } \\
5 \text { million of } \\
\text { yuans (about } \\
0.58 \text { million } \\
\text { Euro). }\end{array}$ & None & $\begin{array}{l}\text { Companies with } \\
\text { shares at a } \\
\text { number of } \\
\text { exchanges. } \\
\text { Companies with } \\
\text { shares of their } \\
\text { controllers at a } \\
\text { number of } \\
\text { exchanges. } \\
\text { Non-profit } \\
\text { organization } \\
\text { distributing the } \\
\text { gained profit. } \\
\text { Companies from } \\
\text { members of } \\
\text { Eurasian } \\
\text { Economic } \\
\text { Union. } \\
\text { Companies from } \\
\text { countries of a } \\
\text { "white list" } \\
\text { where an } \\
\text { effective rate is } \\
\text { by } 75 \% \text { higher } \\
\text { than the Russian } \\
\text { rate. }\end{array}$ \\
\hline $\begin{array}{l}\text { 7) Profit } \\
\text { qualification and a } \\
\text { possibility of } \\
\text { integration of the } \\
\text { taxable base of a } \\
\text { CFC with the } \\
\text { taxable base of a } \\
\text { participant (nominal } \\
\text { dividends or profit } \\
\text { from operations; } \\
\text { deduction of the } \\
\text { costs of a CFC from } \\
\text { income of the } \\
\text { person and etc.). }\end{array}$ & $\begin{array}{l}\text { Profit of subsidiaries } \\
\text { is assumed to be } \\
\text { "nominal dividends" } \\
\text { for the taxation } \\
\text { purposes and CFC's } \\
\text { profit can't be } \\
\text { integrated with the } \\
\text { taxable base of a } \\
\text { taxpayer. } \\
\text { Profit of permanent } \\
\text { representative offices } \\
\text { is assumed to be } \\
\text { profit from operations } \\
\text { and can be integrated } \\
\text { with the base of a } \\
\text { taxpayer. }\end{array}$ & $\begin{array}{l}\text { CFC's profit can be } \\
\text { integrated with the base } \\
\text { of a taxpayer. }\end{array}$ & $\begin{array}{l}\text { Profit of } \\
\text { subsidiaries is } \\
\text { assumed to be } \\
\text { "nominal } \\
\text { dividends" for } \\
\text { the taxation } \\
\text { purposes and } \\
\text { CFC's profit } \\
\text { can't be } \\
\text { integrated with } \\
\text { the taxable } \\
\text { base of a } \\
\text { taxpayer. } \\
\text { Profit of } \\
\text { permanent } \\
\text { representative } \\
\text { offices is } \\
\text { assumed to be } \\
\text { profit from } \\
\text { operations and } \\
\text { can be } \\
\text { integrated with } \\
\text { the base of a } \\
\text { taxpayer. }\end{array}$ & $\begin{array}{l}\text { CFC's profit can be } \\
\text { integrated with the } \\
\text { base of a taxpayer. }\end{array}$ & $\begin{array}{c}\text { CFC's profit } \\
\text { can be } \\
\text { integrated } \\
\text { with the base } \\
\text { of a taxpayer. }\end{array}$ & $\begin{array}{l}\text { CFC's profit } \\
\text { is considered } \\
\text { to be the } \\
\text { profit from } \\
\text { operations } \\
\text { and can be } \\
\text { optionally be } \\
\text { integrated or } \\
\text { not integrated } \\
\text { with the base } \\
\text { of a taxpayer. } \\
\text { Profit of a } \\
\text { CFC from a } \\
\text { "black list" } \\
\text { (tax haven) } \\
\text { and "grey } \\
\text { list" } \\
\text { (countries not } \\
\text { sharing } \\
\text { information) } \\
\text { can't be } \\
\text { integrated. }\end{array}$ & $\begin{array}{l}\text { CFC's profit is } \\
\text { considered to be } \\
\text { the profit from } \\
\text { operations for } \\
\text { the taxation } \\
\text { purposes. } \\
\text { CFC's profit can } \\
\text { be integrated } \\
\text { with the base of } \\
\text { a taxpayer. }\end{array}$ \\
\hline $\begin{array}{l}\text { 8) Administration } \\
\text { (the rules of profit } \\
\text { calculation: local } \\
\text { legislation or } \\
\text { legislation of the } \\
\text { country of a CFC; a } \\
\text { duty to notify of } \\
\text { participation in a } \\
\text { CFC) }\end{array}$ & $\begin{array}{l}\text { Profit is calculated } \\
\text { according to the rules } \\
\text { of the local } \\
\text { legislation. } \\
\text { A duty to notify of } \\
\text { participation in a } \\
\text { CFC. }\end{array}$ & $\begin{array}{l}\text { Profit is calculated } \\
\text { according to the rules of } \\
\text { the local legislation. } \\
\text { A duty of regular } \\
\text { reporting profit } \\
\text { transferred to a foreign } \\
\text { company in statements } \\
\text { and carrying out tests } \\
\text { defining whether the } \\
\text { foreign company is a } \\
\text { CFC. }\end{array}$ & $\begin{array}{l}\text { Profit is } \\
\text { calculated } \\
\text { according to } \\
\text { the rules of the } \\
\text { local } \\
\text { legislation. } \\
\text { A duty to } \\
\text { notify of } \\
\text { participation in } \\
\text { a CFC. }\end{array}$ & $\begin{array}{l}\text { Profit is calculated } \\
\text { according to the } \\
\text { rules of the local } \\
\text { legislation. } \\
\text { A duty to notify of } \\
\text { participation in a } \\
\text { CFC. } \\
\text { There are strict } \\
\text { requirement } \\
\text { concerning keeping } \\
\text { and delivering } \\
\text { reports with regard } \\
\text { to a CFC (there are } \\
\text { heavy fines for their } \\
\text { violation). }\end{array}$ & $\begin{array}{l}\text { Profit is } \\
\text { calculated } \\
\text { according to } \\
\text { the rules of } \\
\text { the local } \\
\text { legislation. } \\
\text { A taxpayer } \\
\text { fills in an } \\
\text { annual } \\
\text { statement on } \\
\text { foreign } \\
\text { investments } \\
\text { and the tax } \\
\text { authority } \\
\text { detects a fact } \\
\text { of CFC } \\
\text { existence. }\end{array}$ & $\begin{array}{l}\text { Profit is } \\
\text { calculated } \\
\text { according to } \\
\text { the rules of } \\
\text { the local } \\
\text { legislation. } \\
\text { A duty to } \\
\text { notify of } \\
\text { participation } \\
\text { in a CFC. }\end{array}$ & $\begin{array}{l}\text { Profit is } \\
\text { calculated } \\
\text { according to the } \\
\text { rules of the local } \\
\text { legislation. } \\
\text { A duty to notify } \\
\text { of participation } \\
\text { in a CFC. }\end{array}$ \\
\hline
\end{tabular}

\section{Copyrights}

Copyright for this article is retained by the author(s), with first publication rights granted to the journal.

This is an open-access article distributed under the terms and conditions of the Creative Commons Attribution license (http://creativecommons.org/licenses/by/3.0/). 